\title{
Analisis Pengaruh Harmonisa Terhadap Rugi-Rugi Daya (Losses) Pada Transformator di Penyulang Sedap Malam
}

\author{
I.G Ariana ${ }^{1}$,I.W. Rinas ${ }^{2}$, I.G.D Arjana ${ }^{3}$
}

\begin{abstract}
The aim of this study is to analyze the influence of harmonic to power losses in transformator atSedapMalam feeder by using the help of ETAP power station, so we can obtain how much the influence of harmonic in distribution system. By measuring THDv and THDi in DT0042, DT0048 and DT0319 transformator we got THDv value of $1.1 \%$ in DT0042, $1.56 \%$ in DT 48 and $1.23 \%$ in DT0319 from maximum margin of $5.0 \%$ in THDV according to IEEE 519-1992 standard. As for THDi we got the value of $9.36 \%$ in DT0042, $12.4 \%$ in DT0048 and $14.2 \%$ in DT0319 from maximum margin of $8.0 \%$ in THDi according to IEEE 519 1992 standard. On other side, the result by running ETAP power station we got THDi value of $1.59 \%$ in D00T42, $1.95 \%$ in DT0048 and $1.71 \%$ in DT0319. As for THDv we got running result of $12.22 \%$ in DT0042, $12.96 \%$ in DT0048 and $13.54 \%$ in DT0319.

Based on the result of performed analisis of the influence of harmonic to power losses in transformator at SedapMalam feeder, we obtained that the amount of power losses was 43,2 $\mathrm{kW}$ before having harmonic and 45,7 kW after having harmonic. The raise of 2,5 $\mathrm{kW}$ was caused by occurance of harmonic in DT0042, DT0048 and DT0319 transformator from total of 44 existed transformators Keywords :Distribution, Harmonic,THDv,THDi, Power Losses.
\end{abstract}

Intisari-Penelitian ini menganalisis pengaruh harmonisa terhadap rugi-rugi daya (losses) pada Transformator di peyulang Sedap Malam menggunakan bantuan ETAP power station, sehingga dapat diketahui hasil seberapa besar pengaruh harmonisa pada system distribusi. Hasi lpengukuran THDv dan THDi pada Transformator DT0042, DT0048 dan DT0319 dari diperoleh hasil THDv sebesar 1,1\% pada DT0042, 1,56\% pada DT0048 dan 1,23\% pada DT0319 dari batas maksimum THDV menurut standar IEEE 519-1992 adalah 5.0\%. Untuk hasil pengukuran THDi didapatkan hasi lpengukuran sebesar 9,36\% pada DT0042. 12,4\% pada DT0048 dan 14,2\% pada DT0319 dari batas maksimum THDi menurut standar IEEE 519 - 1992 adalah $8.0 \%$. Sedangkan untuk hasil running ETAP power station hasil THDi yang didapatkan sebesar 1,59\% pada DT0042. 1,95\% pada DT0048 dan 1,71\% pada DT0319 untuk hasil THDv di dapatkan hasil running sebesar 12,22\% pada DT0042. 12,96\% pada DT0048 dan 13,54\% pada DT0319. Berdasarkan hasil analisis yang telah dilakukan pengaruh harmonisa terhadap rugi-rugi daya (losses) pada

\footnotetext{
${ }^{I}$ Mahasiswa Teknik Elektro dan Komputer Fakultas Teknik Universitas Udayana, Kampus Bukit Jimbaran, Badung Bali.80361, Tel. 0361703315 fax. 0361703315; email :igede.ariana@yahoo.com

${ }^{2,3}$ Dosen Teknik Elektro dan Komputer Fakultas Teknik Universitas Udayana, Kampus Bukit Jimbaran, Badung Bali.80361, Tel. 0361703315 fax. 0361703315; email :rinas@unud.ac.id
}

transformator di penyulang Sedap Malam didapatkan hasil rugirugi daya sebesar 43,2 $\mathrm{kW}$ sebelum adanya harmonisa dan setelah adanya harmonisa menjadi $45,7 \mathrm{~kW}$ peningkatan sebesar $2,5 \mathrm{~kW}$ ini di dapatkan dengan masuknya harmonisa di Transformator DT0042, DT0048 dan DT0319 dari total Transformator yang ada sebanyak 44 buah.

Kata kunci:Distribusi, Harmonisa, THDv,THDi,Rugi Daya

\section{Pendahuluan}

Kebutuhan energi listrik akan terus bertambah seiring dengan berkembangnya teknologi baru terutama pada pengoprasian peralatan modern yang menggunakan rangkaian elektronika daya seperti penggunaan lampu LED. Dengan adanya rangkaian elektonika daya tersebut menyebabkan timbulnya harmonisa yang berdampak pada peningkatan rugirugi daya transformator.

Penyulang Sedap Malam adalah salah satu penyulang yang mendapat suplai dari gardu induk Sanur. Penyulang Sedap malam mensuplai 44 buah transformator distribusi 20 $\mathrm{kV}$ dengan karakteristik beban yang berbeda-beda seperti beban perindustrian, pertokoan, perkantoran, fasilitas umum dan perumahan. yang tersebar di beberapa lokasi untuk melayani konsumen. Hal ini akan mengakibatkan semakin meningkatnya kebutuhan akan tenaga listrik di kawasan tersebut. Dengan kata lain, dengan semakin bertambahnya pemakaian teknologi elektronika daya dalam sistem tenaga listrik maka semakin bertambah juga peralatan beban non linier yang digunakan. Peralatan beban non linier ini dapat mempengaruhi kualitas daya, dikarena beban non linier adalah sumber utama dari gangguan harmonisa yang berpengaruh pada sistem distribusi daya listrik

Harmonisa merupakan suatu fenomena yang timbul akibat pengoperasian beban listrik non linier, sebagai sumber terbentuknya gelombang pada frekuensi-frekuensi tinggi yang merupakan kelipatan dari frekuensi fundamentalnya [1]. Harmonisa juga mempunyai pengaruh pada sistem distribus listrik. Salah satu komponen dalam sistem distribusi listrik adalah transformator.Tingginya kandungan harmonisa yang terdapat pada beban listrik atau pada sistem distribusi

tenaga listrik, dapat mengakibatkan kualitas daya menjadi lebih buruk, karena faktor daya sistem menjadi lebih rendah, bentuk gelombang tegangan sistem terdistorsi, rugi-rugi daya pada sistem meningkat, pemanasan lebih padatransformator, dan penggunaan energi listrik menjadi tidak efisien [2]. 
Berdasarkan data hasil pengukuran yang diperoleh pada tegangan rendah (TR) di penyulang Sedap Malam pada tiga transformator yaitu DT0042 yang terletak di ujung, DT0048 yang terletak di tengah dan DT0319 yang terletak di pangkal, memiliki THD arus yang cukup tinggi dan melebihi standar maksimum IEEE 159-1992. Dilihat dari pengukuran awal nilai THD arus pada transformator

di Penyulang Sedap Malam di dapatkan hasil pengukuran yaitu untuk transformator DT0042; 9,36\%, transformator DT0048; 12,4\%, dan transformator DT0319; $14,2 \%$, dari hasil pengukuran di tiga transformator tersebut diperoleh hasil harmonisa beban yang cukup tinggi sebesar $14,2 \%$ yang letaknya pada transformator DT0319. Kondisi tersebut melebihi nilai standar maksimum IEEE 159-1992 untuk THD arus sebesar $8 \%$. Sedangkan hasil pengukuran untuk nilai THD tegangan pada transformator di Penyulang Sedap Malam, di dapatkan hasil pengukuran THD tegangan yaitu untuk transformator DT0042; 1,1\%, transformator DT0048; 1,56\%, dan transformator DT0319; $1,23 \%$, dimana kondisi tersebut masih memenuhi standar THD tegangan maksimum IEEE 159-1992 yang telah ditentukan yaitu sebesar $\leq 5 \%$ untuk tegangan $\leq 69 \mathrm{kV}[3]$.

\section{TOTAL HARMONIC Distorstion (HARMONISA)}

\section{A. Harmonisa}

Definisi harmonisa. Harmonisa menurut Electrotecnical Commision(IEC) 6100-2-1-1990 didefinisikan sebagai tegangan arus sinusoidalyang memiliki frekuensi sistempasokantenagalistriknyasebagaimana yang dirancanguntukdioperasikan ( $50 \mathrm{~Hz}$ atau $60 \mathrm{~Hz}$ ). Miripdengan IEC, Institute of Electrical and Electronic Engineering (IEEE) Std 1159-1995 mendefenisikanharmonisasebagaiteganganatauarus sinusoidal yang mempunyaikelipatanbulatdarifrekuensidimana system tenagalistrikpasokannyadirancanguntukdioperasikan[3].

\section{B. Beban linier}

Beban yang komponen arusnya tidak proporsional terhadap komponen tegangannya disebut beban non linier, sehingga bentuk gelombang arus maupun tegangan keluarannya tidak sama dengan gelombang masukannya (mengalami distorsi). Contoh beban non linier berupa aplikasi elektronika daya antara lain adalah penyearah (power supply, UPS, komputer, pengaturan kecepatan motor, lampu-lampu pelepasan), alat-alat ferromagnetik, motor DC, dan tungku busur api, serta lainnya. Gambar 1 menunjukan arus yang diserap oleh beban nonlinier

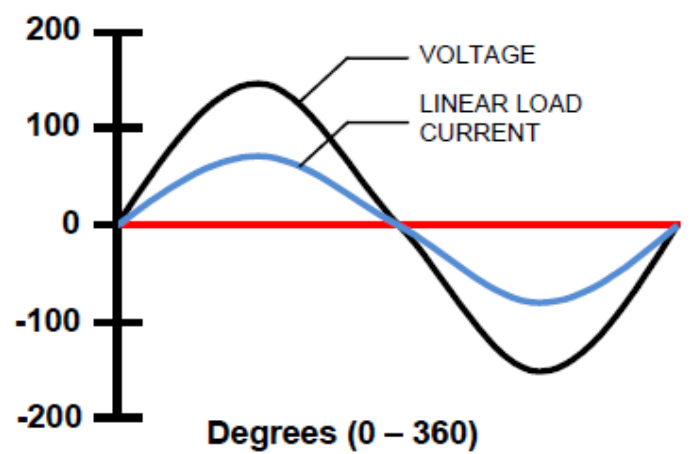

Gambar 1: Bentuk gelombang arus dan tegangan pada beban linier

C. Beban non linier

Bebannon linier murupakan beban yang komponenarusnyatidakproporsionalterhadapkomponentegang annyadisebutbeban non linier, sehinggabentukgelombangarusmaupuntegangankeluarannyati daksamadengangelombangmasukannya (mengalamidistorsi). Contohbeban non linier berupaaplikasielektronikadayaantara lain adalahpenyearah (power supply, UPS, komputer, pengaturankecepatan motor, lampu-lampupelepasan), alatalatferromagnetik, motor DC, dantungkubusurapi, sertalainnya. Gambar 1 menunjukanarus yang diserapolehbebannonlinier. [4]

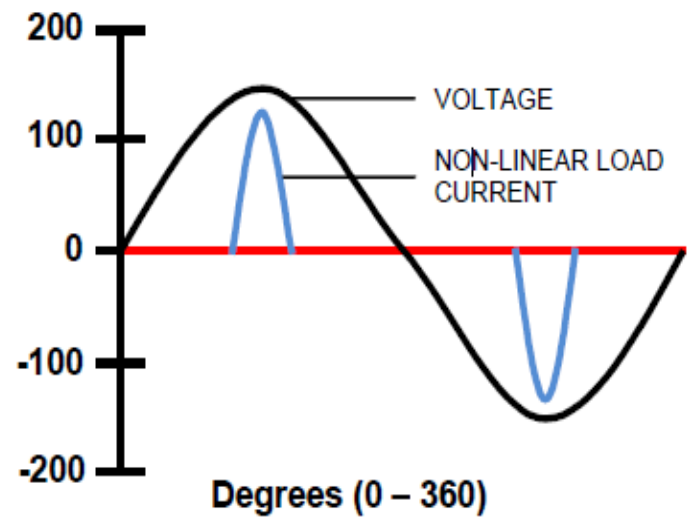

Gambar2:Arus yang diserapolehbeban non linier [4]

D. Total Harmonic Distorstion (THD)

Pada sistem tenaga listrik untuk melihat atau mengetahui berapa besarkandungan distorsi harmonisapada suatukomponenfundamentalnyadiistilahkandengan $T H D$ atauTotal Harmonic Distortion. Persentase Total DistorsiHarmonisaatauTotal Harmonic Distortion (THD) dapat dilihat pada persamaan 2 dan 3.[5]

$$
T H D_{V}=\frac{\sqrt{\sum_{2}^{h} V_{h}^{2}}}{V_{1}} \times 100 \%
$$

Dengan:

$\mathrm{V}_{\mathrm{h}}=$ Komponenharmonisateganganke- $\mathrm{h}$

$\mathrm{V}_{1}=$ Teganganfrekwensi fundamental(rms)

THD untuk arus dapat ditentukan dengan persamaan

I GedeAriana :Analisis Pengaruh Harmonisa Terhadap... 
yang sama, dapat dilihat persamaan 3 .

$$
T H D_{I}=\frac{\sqrt{\sum_{2}^{h} I_{h}^{2}}}{I_{1}} \times 100 \%
$$

Dengan:

$\mathrm{I}=$ Komponenharmonisaaruske-h

$\mathrm{I}_{1}=$ Arusfrekwensi fundamental (rms)[5]

Mengacu pada Standard IEEE 519-1992, untuk dapat menentukan standar batas maksimum THDi pada utility, maka harus diketahui terlebih dahulu rasio hubung singkat (shortcircuit ratio). SCratio dapat dicari dengan menggunakan rumus

$$
\mathrm{SC}_{\text {ratio }}=\frac{I_{S C}}{I_{L}}
$$

Sedangkan $\mathrm{I}_{\mathrm{L}}$ (Arusbebanmaksimum) dapatdicaridenganrumus:

$$
\mathrm{I}_{\mathrm{L}}=\frac{K W}{P F \cdot \sqrt{3} \cdot K V}
$$

E. Pengaruh Harmonisa Pada Transformator

Pada sebuah transformator, rugi-rugi yang disebabkan oleh harmonisa arus dan tegangan bergantung pada frekuensi. Peningkatan frekuensi menyebabkan peningkatan rugi-rugi. Harmonisa frekuensi tinggi adalah penyebab pemanasan utama dibandingkan dengan harmonisa frekuensi rendah. Harmonisa arus menyebabkan peningkatan rugi-rugi tembaga dan rugi-rugi fluks. Sedangkan harmonisa tegangan menyebabkan peningkatan rugirugi besi bocor dan peningkatan stress pada isolasi. Efek keseluruhannya adalah pemanasan berlebih yang terjadi bila dibandingkan dengan operasi dengan gelombang sinus murni. Transformator dirancang untuk menyalurkan daya listrik yang dibutuhkan ke beban dengan rugi-rugi minimum yang diijinkan pada frekuensi fundamentalnya. Arus harmonisa dan juga tegangan secara signifikan akan menyebabkan panas lebih pada transformator. [4]

F. IEEE Standard 519-1992.

TABEL I

BATAS DISTORSI TEGANGAN HARMONIK UTILITY.[6]

\begin{tabular}{|c|c|c|c|c|c|c|}
\hline \multicolumn{7}{|c|}{ Maximum Harmonics Current Distortion $\boldsymbol{I}_{\boldsymbol{\pi}} \% \mathrm{I}_{\boldsymbol{l}}$} \\
\hline \multicolumn{7}{|c|}{ Individual Harmonic Order (Odd Harmonics) } \\
\hline $\mathrm{I}_{\mathrm{sc}} / \mathrm{I}_{\mathrm{L}}$ & $<11$ & $\begin{array}{c}11=<\mathrm{h} \\
<17\end{array}$ & $\begin{array}{c}17=<\mathrm{h} \\
<23\end{array}$ & $\begin{array}{c}23=<\mathrm{h} \\
<35\end{array}$ & $35=<\mathrm{h}$ & $\mathrm{THD} \%$ \\
\hline$<20$ & 4 & 2 & 15 & 0.6 & 0.3 & 5 \\
\hline $\begin{array}{c}20- \\
50\end{array}$ & 7 & 3.5 & 2.5 & 1 & 0.5 & 8 \\
\hline $50-$ & 10 & 4.5 & 4 & 1.5 & 0.7 & 12 \\
\hline
\end{tabular}

I GedeAriana : Analisis Pengaruh Harmonisa Terhadap...

\begin{tabular}{|c|c|c|c|c|c|c|}
\hline 100 & & & & & & \\
\hline $\begin{array}{c}100- \\
1000\end{array}$ & 12 & 5.5 & 5 & 2 & 1 & 15 \\
\hline $\begin{array}{c}> \\
1000\end{array}$ & 15 & 7 & 6 & 2.5 & 1.4 & 20 \\
\hline
\end{tabular}

Tabel I menunjukan batas distorsi arus harmonisa yang diijinkan menurut standar IEEE 519-1992

THD harmonisa urutan genap dibatasi $25 \%$ dari harmonisa urutan ganjil di atas, Distorsi arus yang disebabkan sebuah penyearah setengah gelombang DC tidak dijinkan atau tidak termasuk pada tabelI .[6]

TABEL II

BATAS DISTORSI TEGANGAN HARMONIK UTILITY.[6]

\begin{tabular}{|c|c|c|}
\hline Voltage at PCC & $\begin{array}{c}\text { Individual } \\
\text { Voltage } \\
\text { Distortion }(\%)\end{array}$ & $\begin{array}{c}\text { Total } \\
\text { Harmonic } \\
\text { Distortion } \\
\text { THD }(\%)\end{array}$ \\
\hline $69 \mathrm{kV}$ and below & 3 & 5 \\
\hline $69 \mathrm{kV}-161 \mathrm{kV}$ & 1,5 & 2,5 \\
\hline $161 \mathrm{kV}$ & 1 & 1,5 \\
\hline
\end{tabular}

Tabel II menunjukan batas distorsi tegangan harmonisa yang diijinkan menurut standar IEEE 519-1992

\section{METODE PENELITIAN}

Penelitianinidilakukan di PT. PLN (Persero) Area Bali Selatan dan PT PLN (persero) Rayon Denpasar.

Data yang digunakan dalam analisis penelitian ini bersumber dari PT. PLN (Persero) Area Jaringan Bali Selatan dan PT PLN (persero) Rayon Denpasar.Dalam penelitian ini menggunakan jenis data pengukuran dilapangan dan data sekunder. Data sekunder yaitu data yang diambil dari PT. PLN (Persero) Distribusi Bali. 


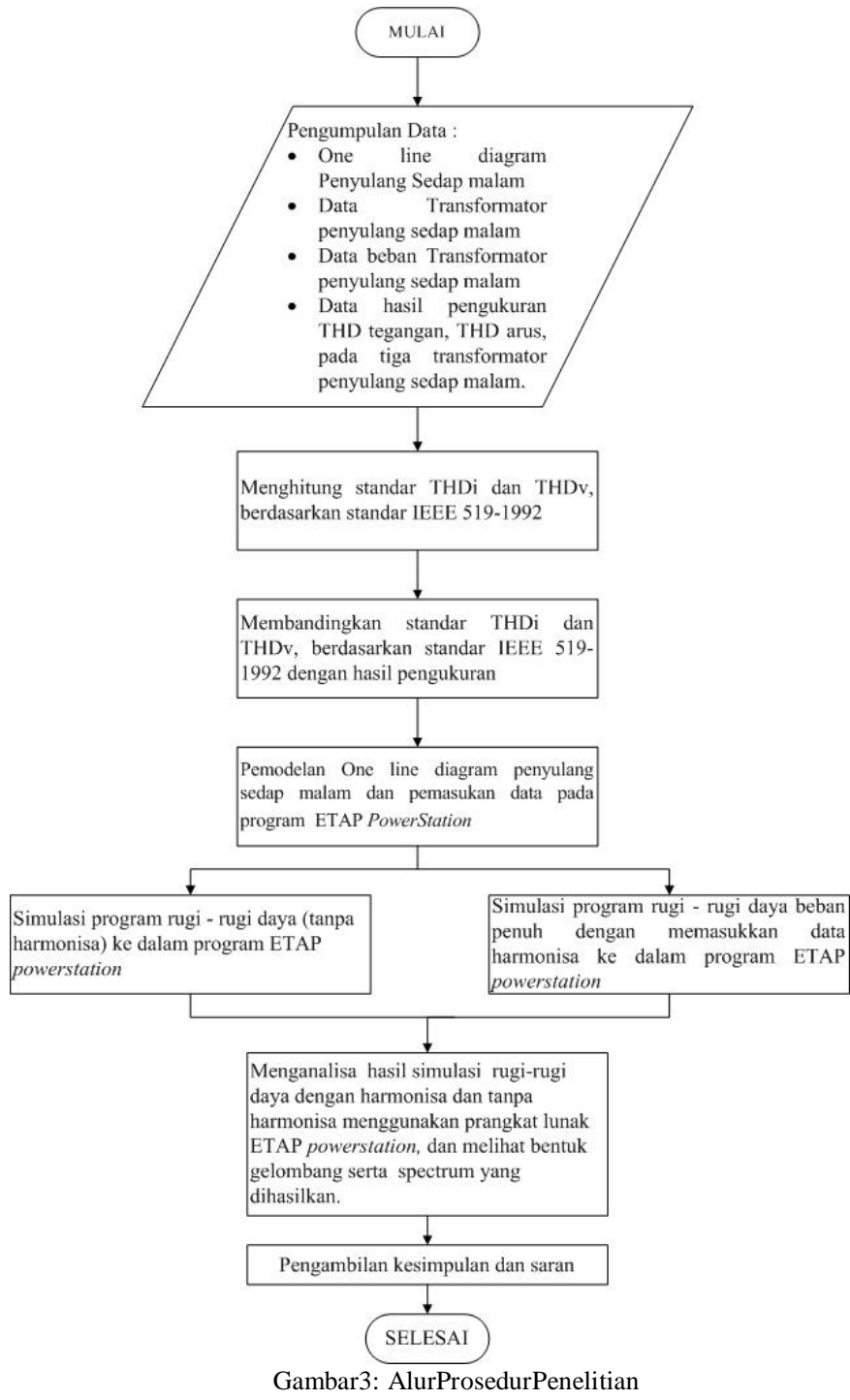

\section{IV.HASIL DAN PEMBAHASAN}

A. GambaranUmumPenyulangSedap Malam

PenyulangSedap Malam mendapatkan suplai daya dari garduindukSanur yang beradadalamwilayah PLN Area Bali Selatan Rayon Denpasar. Penyulang Sedap malam mensuplai 44 buah Transformator distribusi $20 \mathrm{KV}$ dengan karakteristik beban yang berbeda-beda. Penyulang Sedap Malam adalah salah satu penyulang yang berpangkal dari Gardu Induk (GI) Sanur untuk menyalurkan suplai tenaga listrik di daerah Sedap Malam, Kecamatan Denpasar Timur. Berikut ini data-data Penyulalang Sedap Malam Panjang Jaringan Tegangan Menengah: $11.546 \mathrm{~m}$. Panjang Jaringan Tegangan Rendah : 42.195 m. Jumlah Transformator : 44 Unit. Total Daya Transformator : 8075 kVA. Jenis Penghantar: AAAC 150 mm2,AAACS $150 \mathrm{~mm} 2$, MVTIC $150 \mathrm{~mm} 2$, NA2XSEYBY
240 mm2. Jumlah Pelanggan: 8183 Pelanggan Beban Jaringan : $3477,594 \mathrm{kVA}$

B. Batas Maksimum THDi Dan THDv Di Penyulang Sedap Malam

Berdasarkan Standarbatasmaksimum THD Iyang di perbolehkan padasistemkelistrikanmenurut IEEE Standard 519-1992 dapat diketahuidengan rasiohubungsingkat (shortcircuit ratio). $\mathrm{SC}_{\text {ratio }}$ dapatditentukandengan rumus.

$$
\mathrm{SC}_{\text {ratio }}=\frac{\mathrm{I}_{\mathrm{SC}}}{\mathrm{I}_{\mathrm{L}}}
$$

Nilai $\mathrm{I}_{\mathrm{SC}}$ dapatditentukandenganmenggunakanrumus.

$$
I_{s c}=\frac{K V A \times 100}{\sqrt{3} \times K V \times Z(\%)}
$$

C. Batas Maksimum THDi (Arus) Pada Trafo DT0042,

DT0048 Dan DT0319 Di Penyulang Sedap Malam

Menentukan $\mathrm{I}_{\mathrm{SC}}$ dari data trafo DT 42 di Penyulang Sedap Malam dimanadiketahui:KapasitasTrafo $(\mathrm{KVA})=$

160KVA TeganganSekunder $(\mathrm{KV})=380 \mathrm{~V}=$ $0,38 \mathrm{KVImpedansi} \mathrm{Z}(\%)=4 \%$

Maka:

$$
\begin{gathered}
I_{s c}=\frac{K V A \times 100}{\sqrt{3} \times K V \times Z(\%)}=\frac{160 \times 100}{\sqrt{3} \times 0,38 \times 4}=\frac{16.000}{2,62} \\
=6106,87 \mathrm{~A}
\end{gathered}
$$

Jadi Nilai $\mathrm{I}_{\mathrm{sc}}$ yaitu sebesar 6106,87 A

Nilai $\mathrm{I}_{\mathrm{L}}$ ditentukan dengan menggunakan rumus:

$$
\mathrm{I}_{\mathrm{L}}=\frac{\mathrm{KW}}{\mathrm{PF} \sqrt{3} \mathrm{KV}}
$$

Kita dapat menentukan $\mathrm{I}_{\mathrm{L}}$ dimana diketahui Arus beban maksimum trafo DT 42 Penyulang Sedap Malam sebesar $128 \mathrm{KW}$, Power Faktor adalah 0,8 dan Tegangan Sekunder (KV) adalah 0,38 KV. Maka:

$$
\begin{aligned}
& \mathrm{I}_{\mathrm{L}}=\frac{\mathrm{KW}}{\mathrm{PF} \sqrt{3} \mathrm{KV}} \\
& \mathrm{I}_{\mathrm{L}}=\frac{128}{0,8 \sqrt{3} \times 0,38}=\frac{128}{0,52}=246,15 \mathrm{~A} \\
& \text { Untuk mendapatkan nilai } \mathrm{SC}_{\text {ratio }} \text {, nilai } \mathrm{I}_{\mathrm{sc}} \text { dan } \mathrm{I}_{\mathrm{L}} \\
& \text { yang telah didapatkan kemudian dimasukan kedalam } \\
& \text { persamaan Maka perhitungan } \mathrm{SC}_{\text {ratio }} \text { pada DT } 42 \text { di Penyulang } \\
& \text { Sedap Malam adalah sebagai berikut : } \\
& \mathrm{I}_{\mathrm{SC} \quad}=6106,87 \mathrm{~A} \\
& \mathrm{I}_{\mathrm{L}}=246,15 \mathrm{~A}
\end{aligned}
$$

Maka :

$$
\mathrm{SC}_{\text {ratio }}=\frac{\mathrm{I}_{\mathrm{SC}}}{\mathrm{I}_{\mathrm{L}}}=\frac{6106.87}{246,15}=24,80
$$

I GedeAriana :Analisis Pengaruh Harmonisa Terhadap... 
Jadi nilai $\mathrm{SC}_{\text {ratio }}$ pada trafo DT 42 penyulang Sedap Malam yaitu sebesar 24,80.

TABEL III

UNTUK HASIL PERHITUNGAN DT0048 DAN DT0319

\begin{tabular}{|l|c|c|l|}
\hline TRAFO & $I_{S c}$ & $I_{L}$ & $S C_{\text {ratio }}$ \\
\hline DT0048 & $7633,58 \mathrm{~A}$ & $307,69 \mathrm{~A}$ & 24,80 \\
\hline DT0319 & $6106,87 \mathrm{~A}$ & $246,15 \mathrm{~A}$ & 24,80 \\
\hline
\end{tabular}

Tabel III menunjukan hasil perhitungan batas maksimum THDi pada transformator DT0048 danDT039

Batas maximum THDi untuk SCratio berdasarkan Standar IEEE 519-1992 adalah SCratio > 1000 adalah 20\%, untuk SCratio antara 100 sampai dengan 1000 adalah 15\%, untuk SCratio antara 50 sampai dengan 100 adalah $12 \%$, sedangkan untuk SCratio dari 20 sampai 50 nilai THDi yang diijinkan adalah 8\%, dan untuk besar Scratio lebih kecil dari 20 nilai THDi standar yang diijinkan adalah 5\%. Pada sistem kelistrikan di Penyulang Sedap Malam batas maximum THDi yang diperbolehkan dapat dilihat pada tabel 4 .

TABEL IV

BATAS MAKSIMUM THDi MENURUT IEEE 519-1992 DI PENYULANG SEDAP MALAM

\begin{tabular}{|c|c|c|c|}
\hline \multirow[b]{2}{*}{ TEMPAT } & \multicolumn{2}{|l|}{ SCratio } & \multirow[b]{2}{*}{$\begin{array}{l}\text { THDi max } \\
\text { (Sesuai Standar } \\
\text { IEEE 519-1992) }\end{array}$} \\
\hline & $\begin{array}{l}\text { Penyulang } \\
\text { Sedap } \\
\text { Malam }\end{array}$ & $\begin{array}{l}\text { IEEE } \\
\text { Standar } \\
\text { No. } 519 \text { - } \\
1992\end{array}$ & \\
\hline $\begin{array}{l}\text { Trafo } \\
\text { DT0042 }\end{array}$ & 24,80 & $20-50$ & $8 \%$ \\
\hline $\begin{array}{l}\text { Trafo } \\
\text { DT0048 }\end{array}$ & 24,80 & $20-50$ & $8 \%$ \\
\hline $\begin{array}{l}\text { Trafo } \\
\text { DT0319 }\end{array}$ & 24,80 & $20-50$ & $8 \%$ \\
\hline
\end{tabular}

Berdasarkan tabel IV. SC ratio yang pada penyulang Sedap Malam sebesar 24,80 dimana menurut standar IEEE SC ratio dengan rentang 20 sampai dengan 50 batas THDi yang di ijinkan sebesar $8 \%$.

TABEL V

PERBANDINGAN ANTARA NILAI THDI HASIL PENGUKURAN DENGAN STANDAR IEEE 519-1992

\begin{tabular}{|c|c|c|c|}
\hline \multirow[b]{2}{*}{ TEMPAT } & \multicolumn{2}{|c|}{ Kandungan THDI (Arus) } & \multirow[b]{2}{*}{ Keterangan } \\
\hline & $\begin{array}{l}\text { Pengukuran } \\
\text { THDi di } \\
\text { Penyulang } \\
\text { Sedap Malam }\end{array}$ & $\begin{array}{l}\text { IEEE } \\
\text { Standar } \\
\text { No. 519 - } \\
1992\end{array}$ & \\
\hline $\begin{array}{l}\text { Trafo } \\
\text { DT0042 }\end{array}$ & $9,36 \%$ & $8 \%$ & Melebihi Standar \\
\hline
\end{tabular}

I GedeAriana : Analisis Pengaruh Harmonisa Terhadap...

\begin{tabular}{|l|l|l|l|}
\hline $\begin{array}{l}\text { Trafo } \\
\text { DT0048 }\end{array}$ & $12,4 \%$ & $8 \%$ & Melebihi Standar \\
\hline $\begin{array}{l}\text { Trafo } \\
\text { DT0319 }\end{array}$ & $14,2 \%$ & $8 \%$ & Melebihi Standar \\
\hline
\end{tabular}

Pada tabel V memperlihatkan kandungan THDi melebihi batas maksimum yang diijinkan IEEE dimans kandungan THDi (arus) pada trafo DT 0042, DT0048 dan DT 0319 Penyulang Sedap Malammemiliki kandungan THDi diatas $8 \%$.

TABEL VI

PERBANDINGAN THDV PENGUKURAN

DENGAN STANDAR IEEE 519-1992.

\begin{tabular}{|c|c|c|c|}
\hline \multirow[b]{2}{*}{ TEMPAT } & \multicolumn{2}{|c|}{ Kandungan THDv (Tegangan) } & \multirow[b]{2}{*}{ KET } \\
\hline & $\begin{array}{l}\text { Pengukuran di } \\
\text { Penyulang } \\
\text { Sedap Malam }\end{array}$ & $\begin{array}{l}\text { IEEE } \\
\text { Standar No. } \\
519-1992\end{array}$ & \\
\hline $\begin{array}{l}\text { Trafo } \\
\text { DT0042 }\end{array}$ & $1,1 \%$ & $5 \%$ & $\begin{array}{l}\text { Memenuhi } \\
\text { Standar }\end{array}$ \\
\hline $\begin{array}{l}\text { Trafo } \\
\text { DT0048 }\end{array}$ & $1,56 \%$ & $5 \%$ & $\begin{array}{l}\text { Memenuhi } \\
\text { Standar }\end{array}$ \\
\hline $\begin{array}{l}\text { Trafo } \\
\text { DT0319 }\end{array}$ & $1,23 \%$ & $5 \%$ & $\begin{array}{l}\text { Memenuhi } \\
\text { Standar }\end{array}$ \\
\hline
\end{tabular}

Berdasarkan tabel VI. kandungan THDv pada Transformator di penyulang Sedap Malam masih berada di bawah 5\%.

D. Gambar Spectrum Harmoninisa dan gelombang Harmonisa pada DT0042, DT0048, DT0319 penyulang Sedap Malam

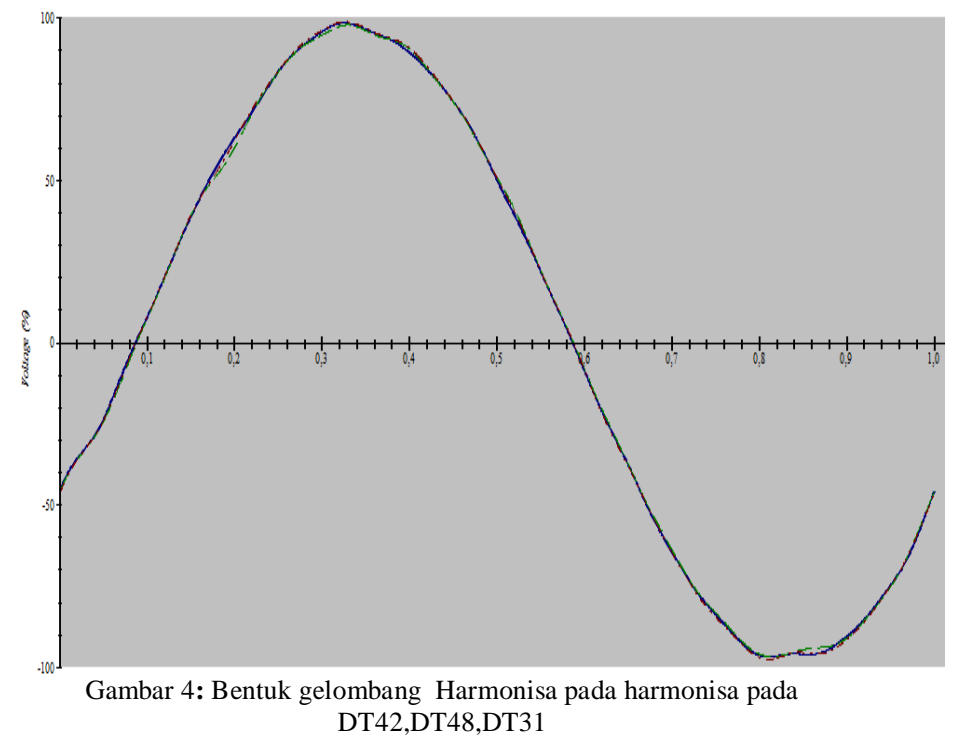

Dari hasil simulasi bentuk gelombang sinusoidal yang di hasilkan menunjukan bahwa terdapat beberapa cacat 
gelombang yang timbul oleh adanya penggunan beban-beban non linier pada sistrm tenaga lisrtik.

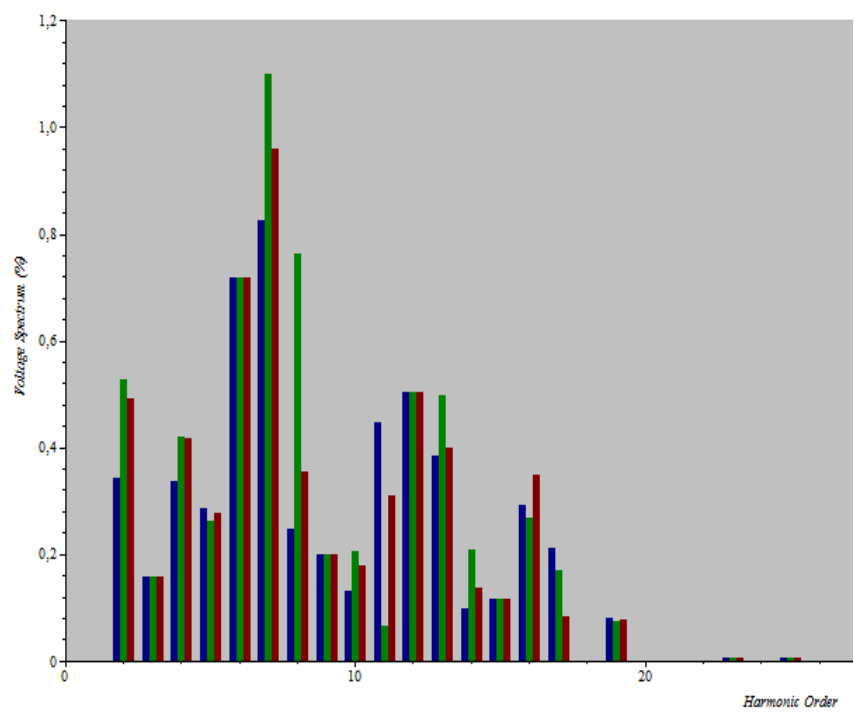

Gambar5:Spektrum harmonisa pada DT0042,DT0048,DT0319

Dari hasil simulasi bentuk Spektrum harmonisa yang dihasilkan menunjukanperbandingan kandungan harmonisa pada tiga transformator di penyulang Sedap Malam yaitu warna biru DT0042, warna hijau DT0048 dan warna merah DT0319.

\section{Ket :}

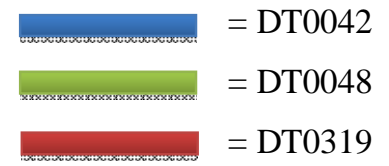

E. Analisis THDi Pada Transformator DT 42,DT48 dan DT 319 penyulang Sedap Malam

Berdasarkan dari hasil perhitungan short-circuit ratio atau SC ratio, menurut IEEE standar 519-1992. Berikut adalah hasil running program kandungan THDi pada Transformator DT 42,DT 48 dan DT 319

\begin{tabular}{|c|c|c|c|c|c|c|}
\hline \multicolumn{2}{|l|}{ Proiest: } & \multicolumn{2}{|c|}{ ETAP } & \multicolumn{2}{|c|}{ Page: } & \\
\hline 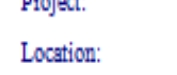 & & \multicolumn{2}{|l|}{$12.6 .0 \mathrm{H}$} & \multicolumn{3}{|l|}{$\begin{array}{l}\text { Datt: } \\
\text { SN: }\end{array}$} \\
\hline Contrat: & & \multirow[b]{2}{*}{ Study Cass: } & \multirow[b]{2}{*}{$\mathrm{HA}$} & \multirow{2}{*}{$\begin{array}{l}\text { Revision } \\
\text { Conffigin }\end{array}$} & \multirow{2}{*}{\multicolumn{2}{|c|}{$\begin{array}{l}\text { Base } \\
\text { Normal }\end{array}$}} \\
\hline $\begin{array}{l}\text { Enginer: } \\
\text { Filengma: } \quad \text { SED }\end{array}$ & MALAM & & & & & \\
\hline \multicolumn{7}{|c|}{ System Harmonics Branch Information } \\
\hline Bus & & & \multicolumn{4}{|c|}{ Current Distortion } \\
\hline From Bus D & To Bus $\mathbb{D}$ & $\begin{array}{l}\text { Fund } \\
\text { Aapp }\end{array}$ & $\begin{array}{l}\text { RNSS } \\
\text { Amp }\end{array}$ & $\begin{array}{l}\text { ASUM } \\
\text { Arp } \\
\end{array}$ & $\begin{array}{l}\text { THD } \\
\% \\
\end{array}$ & $\mathbb{T I F}$ \\
\hline Bur.DTous2 & Bus218 & 107.17 & 10797 & 145.74 & 1222 & 65.66 \\
\hline Bus.DTRQA4R & Bus 135 & 17720 & 178.68 & 24232 & 1296 & 58.10 \\
\hline $\begin{array}{l}\text { Bus.DTro319 } \\
\text { Bus1 }\end{array}$ & Bus18 & 125.80 & 126.94 & 173.57 & 13.54 & 60.00 \\
\hline
\end{tabular}

Gambar 7 menunjukan hasil running menggunakan Software Etap menunjukan bahwa kandungan THDi (arus) pada transformator DT0042,DT0048 dan DT0319 di penyulang Sedap Malam melebihi batas standar yang diijinkan menurut standar IEEE 519-1992 yaitu sebesar 8\%

TABLE VII

PERBANDINGAN THD I ANTARA

HASIL RUNNING MENGGUNAKAN SOFTWARE

ETAP DENGAN STANDARIEEE 519-1992

\begin{tabular}{|c|c|c|c|}
\hline TRAFO & $\begin{array}{c}\text { Hasil running } \\
\mathbf{T H D}_{\mathbf{I}}(\mathbf{\%})\end{array}$ & $\begin{array}{c}\text { IEEE Standar } \\
\mathbf{5 1 9 - \mathbf { 1 9 9 2 }} \\
\mathbf{T H D}_{\text {Imax }}(\mathbf{\%})\end{array}$ & KETERANGAN \\
\hline DT0042 & $12,22 \%$ & $8 \%$ & Melebihi stantar \\
\hline DT0048 & $12,96 \%$ & $8 \%$ & Melebihi stantar \\
\hline DT0319 & $13,54 \%$ & $8 \%$ & Melebihi stantar \\
\hline
\end{tabular}

Tabel VII menunjukan hasil perbandingan THDi (arus) antara hasil running menggunakan software Etap dengan standar IEEE 519-1992 
F. Analisis $\mathrm{THD}_{\mathrm{V}}$ Pada Transformator DT0042,

DT0048 dan DT0319 penyulang Sedap Malam

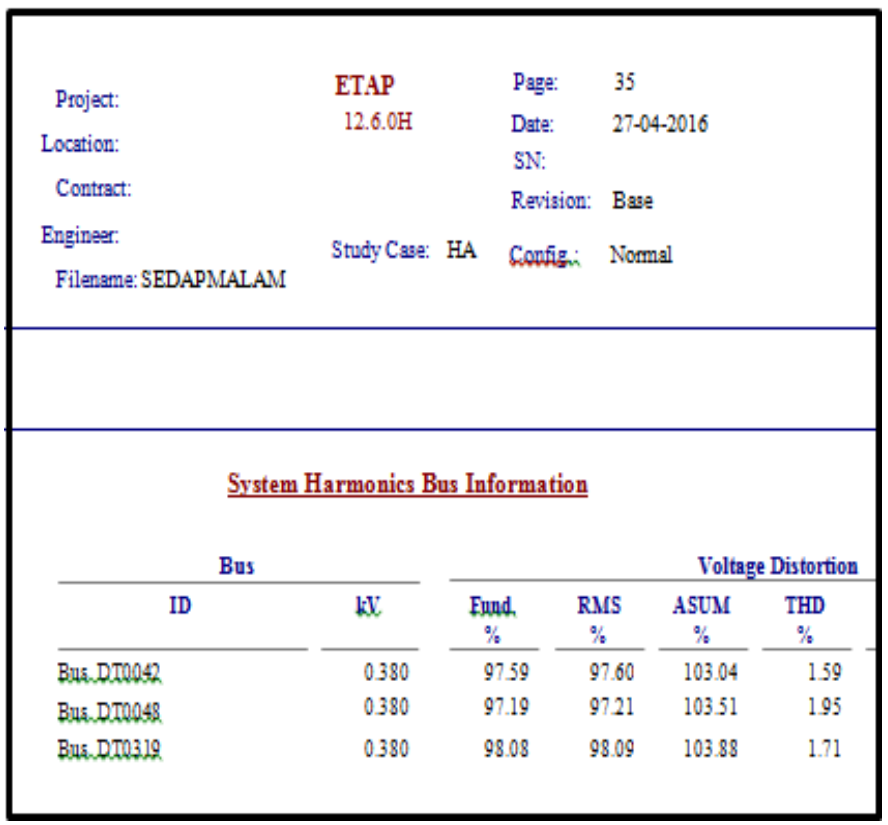

Gambar 8: Tabel Hasil Running THDv(\%) Menggunakan Software Etap

Gambar 8 Hasil running menggunakan Software Etap menunjukan bahwa kandungan harmonisa atau THDv (tegangan) pada transformator DT0042,DT0048 dan DT0319 di penyulang Sedap Malam masih berada dalam batas standar yang diijinkan menurut standar IEEE 519-1992 yaitu sebesar $5 \%$

TABLE VIII

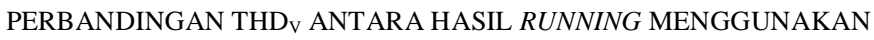
SOFTWARE ETAP DENGAN STANDARIEEE 519-1992

\begin{tabular}{|l|l|l|l|}
\hline TRAFO & $\begin{array}{c}\text { Hasil } \\
\text { running } \\
\text { THD }_{\mathbf{V}}(\mathbf{\%})\end{array}$ & $\begin{array}{c}\text { IEEE Standar } \\
\mathbf{5 1 9 - 1 9 9 2} \\
\mathbf{T H D}_{\text {Imax }}(\boldsymbol{\%})\end{array}$ & KET \\
\hline DT0042 & $1,59 \%$ & $5 \%$ & Memenuhi stantar \\
\hline DT0048 & $1,95 \%$ & $5 \%$ & Memenuhi stantar \\
\hline DT0319 & $1,71 \%$ & $5 \%$ & Memenuhi stantar \\
\hline
\end{tabular}

Tabel VIII menunjukan hasil perbandingan THDv (tegangan) antara hasil running menggunakan software Etap dengan standar IEEE 519-1992

I GedeAriana : Analisis Pengaruh Harmonisa Terhadap...
G. AnalisisRugiDayaPenyulangSedap Malam Tanpa

Harmonisa dan Dengan Harmonisa

DalamanalisahasilRugiDayapada software ETAP terlebihdahulumasukkan parameter - parameter yang diperlukan :

1. Data Transformator

2. Penggunaanbebantransformator

3. Panjangsaluranpenghantar, danjenispenghantar.

Pada simulasi ini digunakan dua kondisi, yaitu pertama pada saat kondisi penyulang Sedap Malam tanpa harmonisa dan kedua pada saat penyulang Sedap Malam dengan harmonisa. Untuk mengetahui pengaruh yang terjadi jika adanya harmonisa pada sistem distribusi $20 \mathrm{KV}$ di penyulang Sedap Malam. Hasil dari simulasi yang telah dijalankan dapat dilihat dari gambar 9 dimana pada hasil running di dapatkan losses atau rugi daya beban sebesar $43,2 \mathrm{~kW}$. hasil tersebut di dapatkan pada saat kondisi penyulang belum adanya harmonisa.

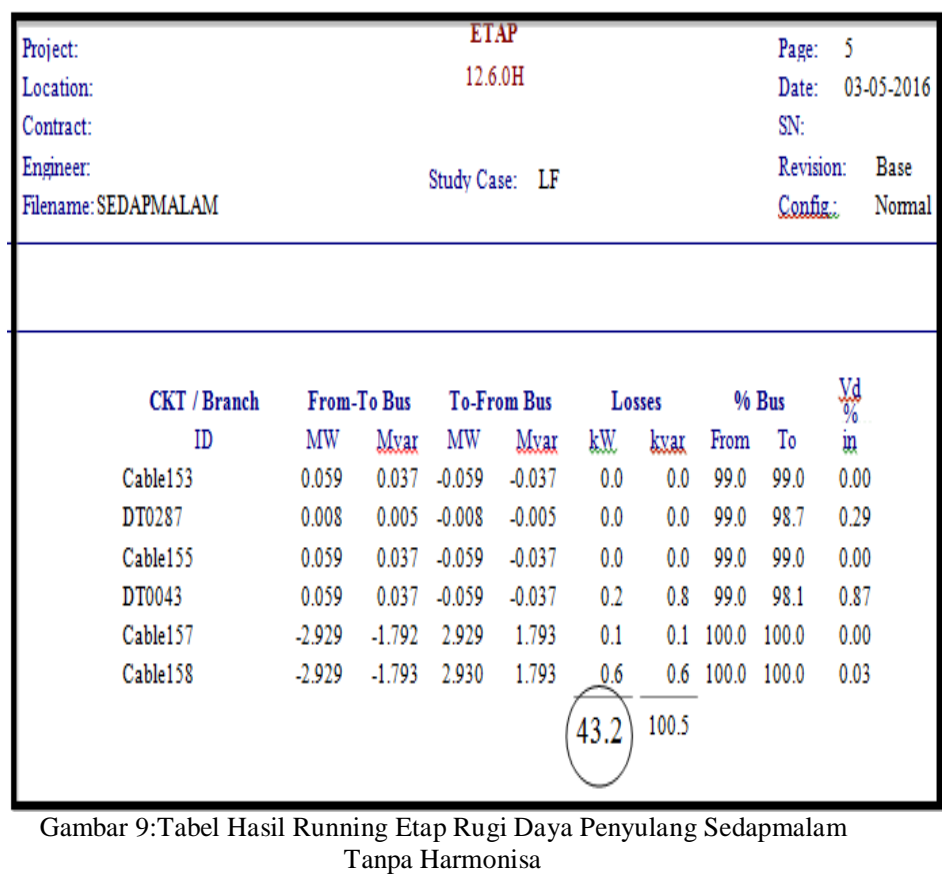

Gambar 9 menunjukan hasil running dari program Etap ketika belum adanya harmonisa.

Simulasi kedua pada saat penyulang Sedap Malam dengan Harmonisa, Dalam analisa hasil Rugi Daya pada software ETAP terlebih dahulu masukkan parameter - parameter yang diperlukan sama seperti parameter diatas namun ditambah dengan harmonisa:

1. Data Transformator

2. Penggunaan beban transformator dengan harmonisa 
3. Memasukan data harmonisa

4. Panjang saluran penghantar, dan jenis penghantar.

Hasil dari simulasi yang telah dijalankan dapat dilihat dari gambar 10 dimana pada hasil running di dapatkan losses atau rugi daya sebesar $45,7 \mathrm{~kW}$. hasil tersebut di dapatkan pada saat kondisi penyulang dengan beban harmonisa.

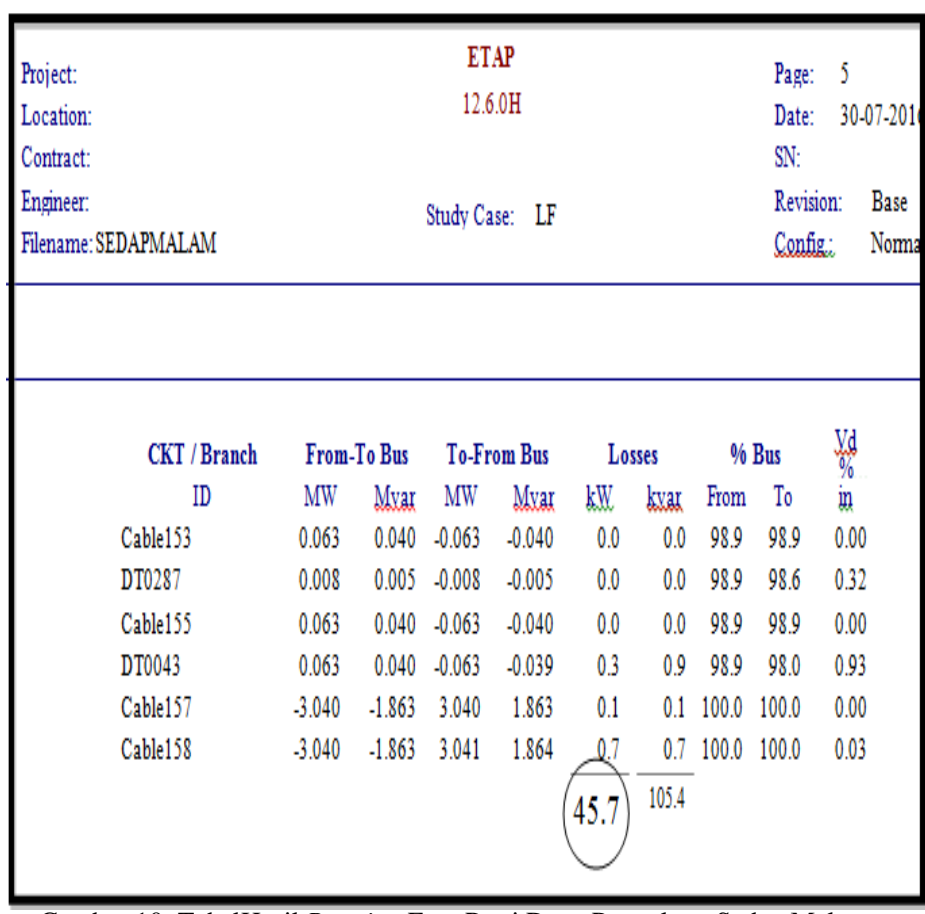

Gambar 10: TabelHasil Running Etap Rugi Daya Penyulang Sedap Malam Dengan Harmonisa

Gambar 10 menunjukan hasil running dari program Etap ketika adanya harmonisa.

Tabel IX

Perbandingannilairugidayasebelumdan sesudahadanya beban harmonisa

\begin{tabular}{|c|c|}
\hline $\begin{array}{c}\text { TANPA } \\
\text { HARMONISA } \\
\text { (KW) }\end{array}$ & $\begin{array}{c}\text { DENGAN } \\
\text { HARMONISA } \\
(\text { KW) }\end{array}$ \\
\hline 43,2 & 45,7 \\
\hline
\end{tabular}

Persentase peningkatan rugi daya setelah adanya beban harmonisa adalah:

$$
\begin{aligned}
& \text { Persentase peningkatan rugi daya } \\
& =[(43,2+45,7): 43,2] \times 100 \% \\
& =0,020 \%
\end{aligned}
$$

Dari tabel IX dapat diketahui bahwa pada Penyulang Sedap Malam peningkatan rugi daya mencapai $0,020 \%$ atau sebesar 2,5 kW.Persentasepeningkatan rugi-rugidaya sebesar $2,5 \mathrm{~kW}$ di peroleh setelah adanyabeban harmonisa pada tiga buah Transformator yang ada di penyulang Sedap Malam. pada running pertama sebelum masuknya beban harmonisa pada tiga Transformator penyulang Sedap Malam, rugi-rugi daya yang di peroleh sebesar $43.2 \mathrm{~kW}$, dan setelah masuknya beban harmonisa rugi-rugi daya meningkat menjadi 45,7 Kw. Hal tersebut dapat membuktikan bahwa harmonisa berpengaruh terhadap rugi-rugi daya yang terjadi pada jaringan distribusi $20 \mathrm{KV}$ yang mengakibatkan minggaktnya nilai losses atau rugi-rugi daya pada penyulang Sedap Malam, dari hasil simulasi pertama menggunakan software ETAP power station diperoleh losses atau rugi-rugi daya tanpa harmonisa sebesar $43,2 \mathrm{~kW}$, dan pada hasil simulasi kedua dengan menggunakan software ETAP power station diperoleh losses atau rugi-rugi daya dengan beban harmonisa menjadi 45,7 kW. Dengan adanya beban harmonisa pada Transforator mengakibatkan losess atau rugi-rugi daya pada penyulang Sedap Malam menjadi meningkatdimana peninggakan losess atau rugi-rugi daya mengakibatkan kenaikan pada penghantar netral sehingga menyebabkan rugi-rugi daya bertambah yang mengakibatkkan timbulnya panas berlebih pada transformator yang dibangkitkan oleh arus beban yang mengandung harmonisa dapat berpengaruh pada kinerja Transformator menjadi terganggu.

\section{SIMPULAN}

Nilai THDi pada saat pengukuran di lapangan sebesar 9,36\% pada Trasformator DT0042, pada Trasformator DT0048 sebesar 12,4\% dan pada Trasformator DT0319 sebesar 14,2\% sedangkan Nilai THDi pada hasil running yaitu sebesar $12,22 \%$ di DT0042, sebesar 12,95 \% di DT0048 dan sebesar 13,54\% di DT0319. Untuk standar nilai THDi hasil pengukuran dan hasil running, dengan standar IEEE 519-1992 menyatakan bahwa nilai THDipada trafo di Penyulang Sedap melebihi ketentuan standar yaitu 8\%. Dengan besarnya kandungan THDi pada Transformator mengakibatkan meningkatnya rugi-rugi daya pada Transformator dikarenakan kenaikan arus pada penghantar netral yang di sebabkan panas berlebih oleh harmonisa . Salah satu cara untuk menanggulang pengaruh harmonisa adalah pesasangan filter harmonisa.

Nilai THDV dari hasil pengukuran di lapangan sebesar 1,1\% pada Trasformator DT0042, pada Trasformator DT0048 sebesar $1,56 \%$ dan pada Trasformator DT0319 sebesar 1,23\% sedangkan Nilai THDV pada hasil running yaitu sebesar $1,59 \%$ di DT0042, sebesar $1,95 \%$ di DT0048 dan sebesar $1,71 \%$ di DT0319. Nilai THDv hasil pengukuran dan hasil running, dengan standar IEEE 519-1992 menyatakan bahwa nilai THDv pada trafo di Penyulang Sedap Malam masih berada diatas ketentuan standar yaitu 5\%.

Dari analisis yang telah dilakukan besarnya harmonisa didapatkan hasil running menggunakan bantuan software ETAP power station pengaruh harmonisa terhadap rugi-rugi daya pada Transformator di penyulang Sedap Malam mengalami peninggatan sebesar $0,020 \%$ atau sekitar $2,5 \mathrm{~kW}$ dimana pada hasilrunning tanpa harmonisa di dapatkan nilai rugi-rugi daya sebesar $43,2 \mathrm{~kW}$ dan setelah masuknya harmonisa rugi-rugi daya menjadi $45,7 \mathrm{~kW}$.

\section{REFERENSI}

[1]. Tanoto, Y. 2005. Simulasi Active Filter dan Sistem Kerja Rangkaian Dalam Meredam Harmonisa pada Vacuum Casting

I GedeAriana :Analisis Pengaruh Harmonisa Terhadap... 
Induction Furnace Dengan Daya 9 kW, 13.8 kVA, 200 V, 3 Fasa , 50/60 Hz. Surabaya : Jurusan Teknik Elektro Universitas Kristen Petra.

[2]. Suweden, Rinas. 2009. Analisa Penanggulangan Thd Dengan Filter Pasif Pada Sistem Kelistrikan Di Rsup Sanglah. Jurnal Teknologi Elektro, Vol. 8 No.2 Juli - Desember 2009

[3]. [3] Rinas, I Wayan, 2013. Simulasi Penggunaan Filter Pasif, Filter Aktif dan Filter Hybrid Shunt untuk Meredam Meningkatnya Distorsi Harmonisa yang Disebabkan Oleh Munculnya Gangguan Resonansi. Jurnal Teknologi Elektro, Vol. 12 No. 2 JuliDesember 2013

[4]. Rinas, I Wayan, 2012. Studi Analisis Losses dan Derating Akibat Pengaruh THD Pada Gardu Transformator Daya Di Fakultas Teknik Universitas Udayana. Jurnal Teknologi Elektro, Vol. 11 No. 1 Januari - Juni 2012

[5]. Limantara.Hybrid Active Filter Untuk Meredam Resonansi Harmonisa Pada Sistem Pembangkitan di Industri. Jurusan Teknik Elektro , Fakultas Teknologi Industri, Universitas Kristen Petra, Jurnal Teknik Elektro Vol. 2, No. 1. 2002.

[6]. Dugan, Roger. et al. 2003. Electrical PowerSystems Quality. New York : McGraw-Hill.2003. 
\{ Halaman ini sengaja dikosongkan \} 